\title{
Effects of Cold Durations on Chilling Injury in Lagenaria Germplasm
}

\author{
Nebahat Sari \\ Department of Horticulture, Cukurova University, 01330, Adana, Turkey
}

Emily Silverman, Danny Reiland, and Todd C. Wehner

Department of Horticultural Science, North Carolina State University, Raleigh, NC 27695-7609

Additional index words. 0-9 scores, cold damage, genetic resources, watermelon rootstocks

Abstract. Cucurbit plants usually are sensitive to chilling and easily damaged. Although bottle gourds, which are members of the Cucurbitaceae family, are considered as fresh vegetables in some Asian countries, their main use in recent years is to be used as rootstocks in grafted watermelon cultivation. We tested 163 bottle gourd accessions of the U.S. Department of Agriculture (USDA) genebank for cold tolerance in the early seedling stage. The experiment was conducted using controlled environment chambers with 3 chilling durations $\left(36,48\right.$, and 60 hours) at $4{ }^{\circ} \mathrm{C}$. Chilling damage was rated 0 to $9(0=$ no damage, 1 to $2=$ trace of damage, 3 to $4=$ slight damage, 5 to $6=$ moderate damage, 7 to $8=$ advanced damage, $9=$ plant totally dead). We rated damage separately for the cotyledons, true leaf, and growing point. Cold damage was higher at a chilling duration of 60 hours, and decreased at 48 and 36 hours. Most tolerant cultigens were PI 491272, PI 491280, PI 491281, PI 491286, and PI 491326. Most susceptible were PI 381845, PI 381846, PI 534556, PI 636137, and PI 668365.

As one of the main environmental factors, low temperature is limiting for crop production. Chilling injury (CI) is a stress caused by low, non-freezing temperatures (0 to $12{ }^{\circ} \mathrm{C}$ ) (Dong et al., 2019). Temperatures below $10{ }^{\circ} \mathrm{C}$ may injure tropical and subtropical crops, such as species of the Cucurbitaceae (Raison, 1974). Although some plants can withstand cold stress, low temperatures during the production of most summer vegetables such as cucurbits can cause reduced growth, leaf yellowing, and foliar necrosis.

Watermelon [Citrullus lanatus (Thunb.) Matsum. \& Nakai] is an economically important cucurbit species belonging to the family Cucurbitaceae. It is cultivated throughout the world and total production is more than 118 million $t$ (FAO, 2017). Grafting of watermelon is an established production practice that contributes resistance to soilborne diseases or tolerance to abiotic stresses (Bertucci et al., 2018). Watermelons are grafted to increase fruit and seed yield and plant growth by enhancing water and plant

Received for publication 28 May 2020. Accepted for publication 29 June 2020.

Published online 18 September 2020.

The seeds used in this study were obtained from the U.S. Department of Agriculture and the study was conducted in North Carolina State University Phytotron. We thank both organizations for their support. We also appreciate Berken Cimen from Cukurova University, Turkey, for his contributions to the statistical analysis.

N.S. is the corresponding author. E-mail: nesari@ cu.edu.tr.

This is an open access article distributed under the CC BY-NC-ND license (https://creativecommons. org/licenses/by-nc-nd/4.0/).
2007; Kozik and Wehner, 2008; Smeets and Wehner, 1997), watermelon (Ghanbari et al., 2018; Kozik and Wehner, 2014; Spalholz and Kubota, 2017), and melon (Diao et al., 2019; Li, 2012; Zhang et al., 2017); however, few studies have been done on bottle gourds (Ko et al., 2006; Liu et al., 2003; Xing et al., 2017), and Lagenaria genetic resources have not been screened for low temperature conditions.

A method for screening seedlings of cucumber for chilling tolerance was developed by Smeets and Wehner (1997) using controlled environmental conditions and cultigens that were tolerant (AR75-79, 'Chipper', 'Pixie', and 'Wisconsin SMR 18') or susceptible (Gy14, 'Marketmore 76', NCSU M28, NCSU M29, and 'Poinsett 76'). Researchers concluded that genetic variation for chilling damage was greater at the first true leaf than at the cotyledon stage. Kozik and Wehner (2014) used a similar method for screening of watermelons. They tested 16 watermelon cultigens using four chilling durations $(6$, 12,24 , or $36 \mathrm{~h}$ ) and 2 chilling temperatures $\left(2\right.$ or $4{ }^{\circ} \mathrm{C}$ ). They found $36 \mathrm{~h}$ at $4{ }^{\circ} \mathrm{C}$ or $24 \mathrm{~h}$ at $2{ }^{\circ} \mathrm{C}$ as optimal conditions for chilling treatment; PI 244018 was the most tolerant cultigen and NH Midget and Golden were the most susceptible cultigens.

USDA-Agricultural Research Service, Plant Genetic Resources and Conservation Unit in Griffin, GA (http://www.ars-grin.gov) has more than 235 PIs of Lagenaria siceraria (Levi et al., 2009). In this study, 163 Lagenaria accessions in USDA were evaluated for tolerance to low temperature.

\section{Materials and Methods}

Plant material. One hundred eighty Lagenaria siceraria accessions from USDA were

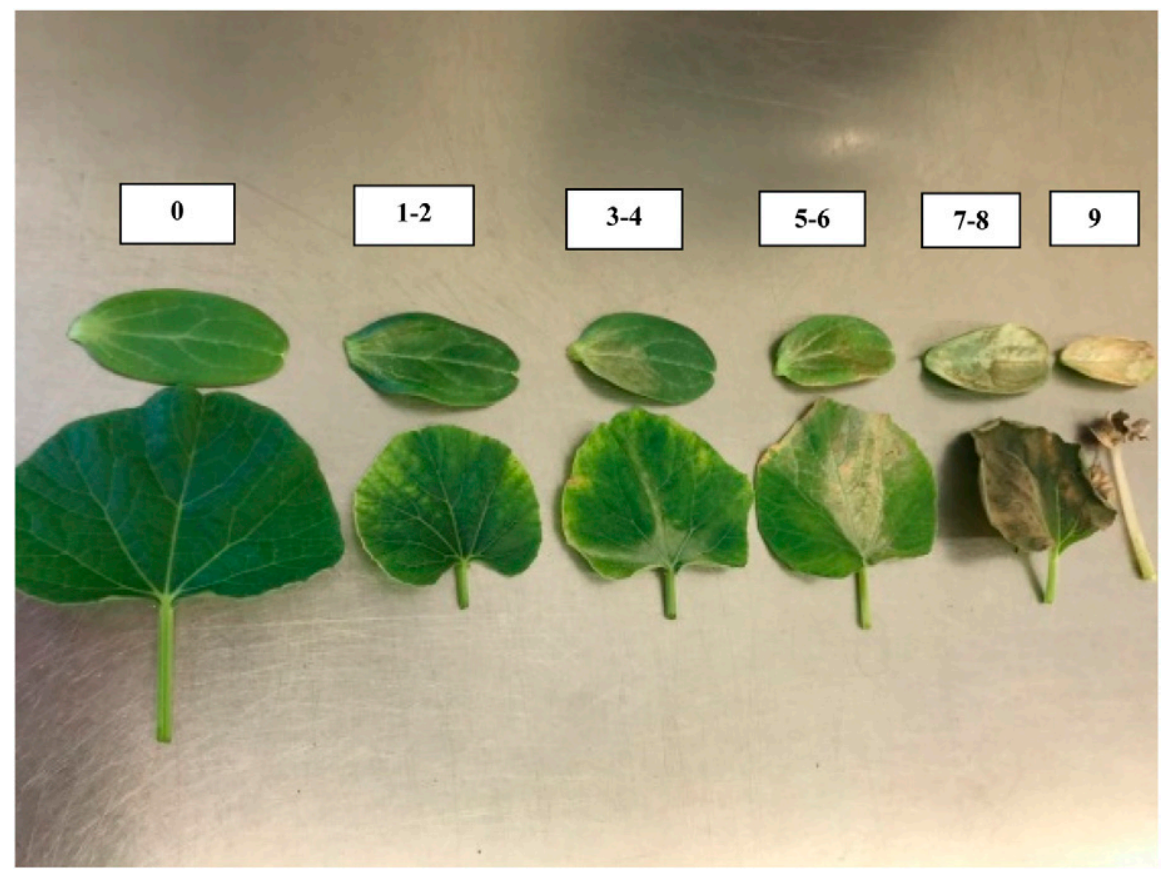

Fig. 1. Rating scale for chilling damage of 0 to $9: 0=$ no damage, 1 to $2=$ trace of damage, 3 to $4=$ slight damage, 5 to $6=$ moderate damage, 7 to $8=$ advanced damage, $9=$ plant dead (left). 
崖

i

送

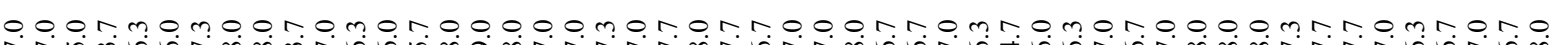

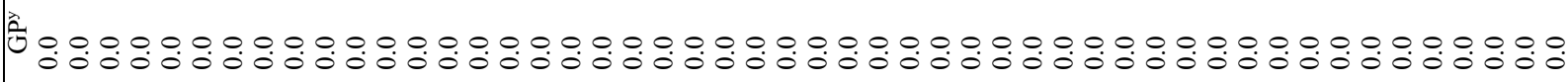

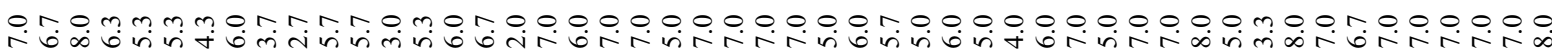

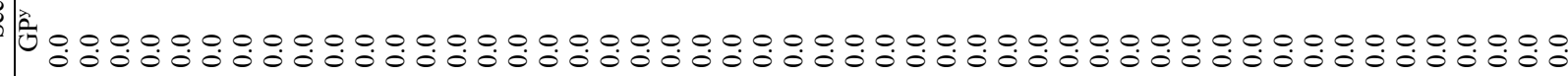

m $\dot{b}_{0}$ o

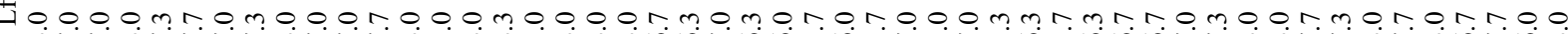

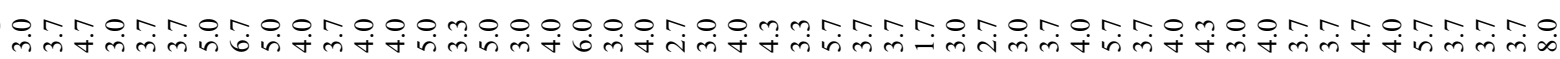

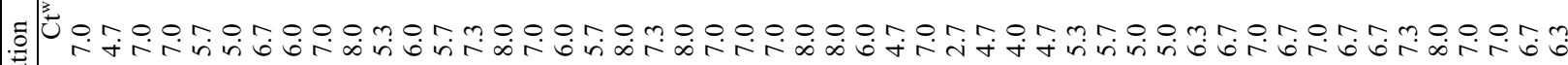

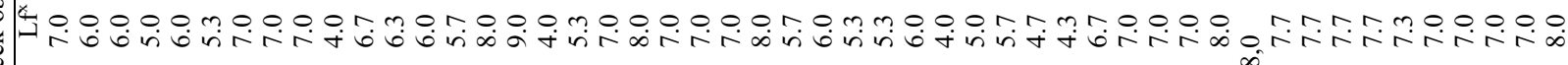
苟

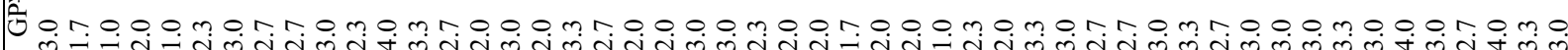
m-

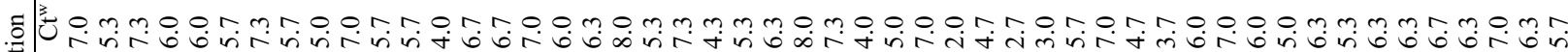

HomnomomomoonommoOnonoonoomoomomnmnomnooonommomnoOm 至

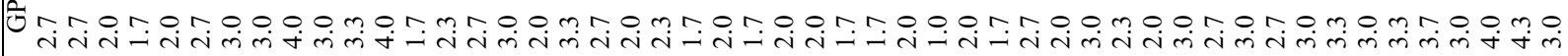

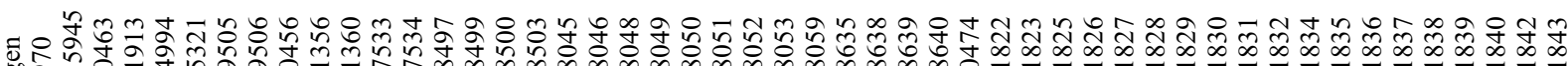

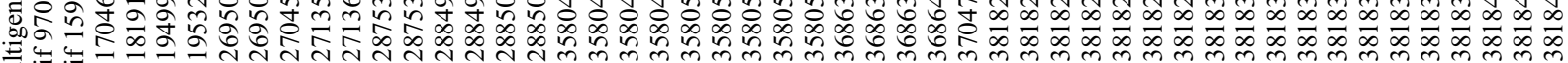

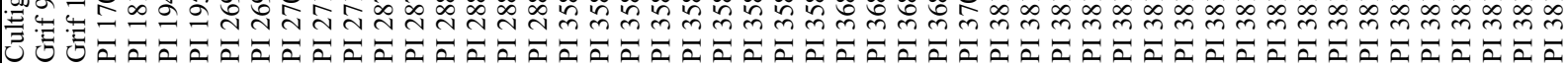




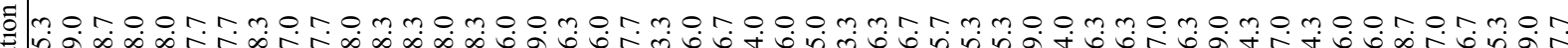

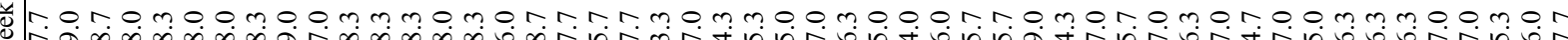

递

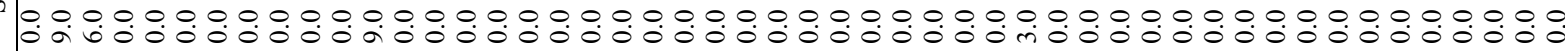

荓

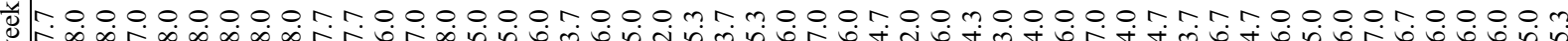

ش

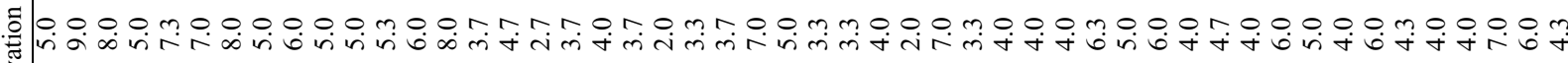

च

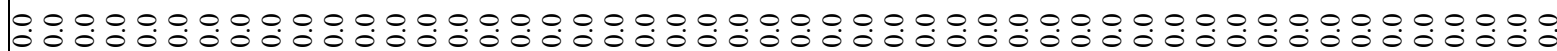

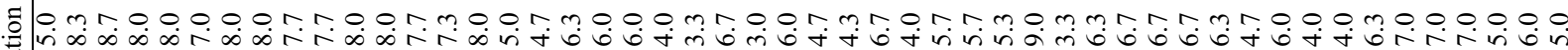

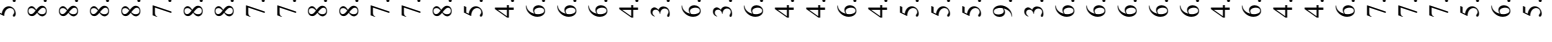

Е

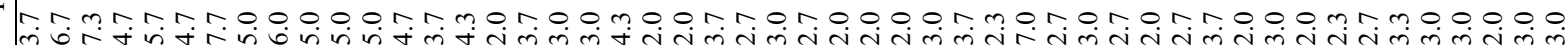

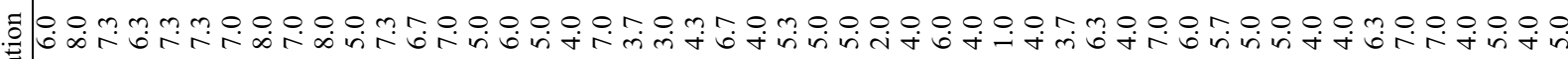

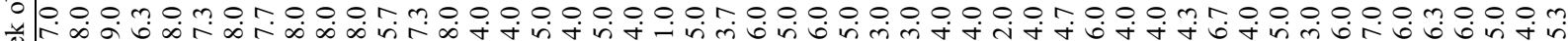

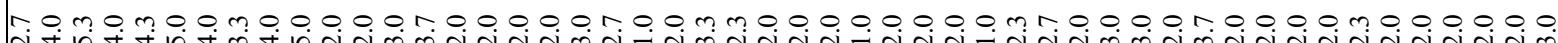

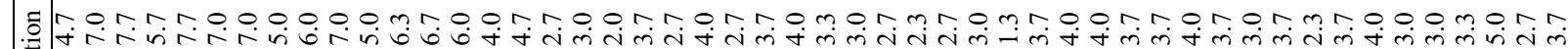

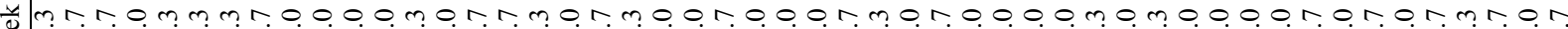
蒡

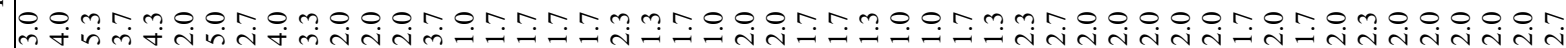

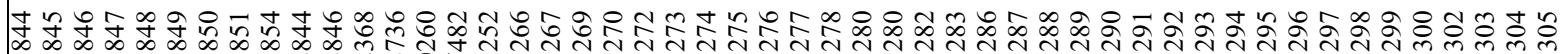

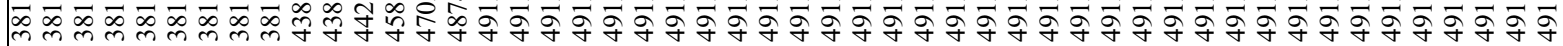

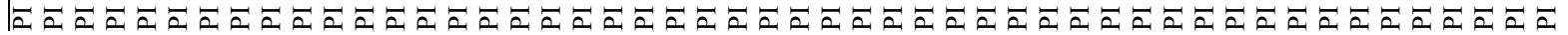




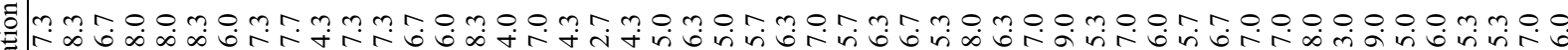

药

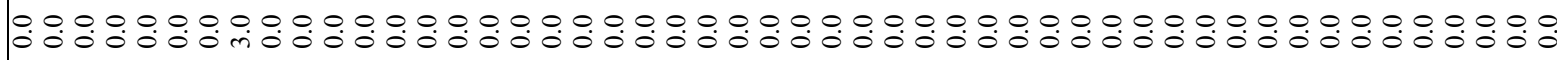

言

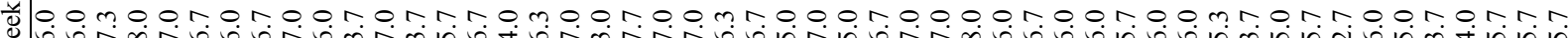

W0000000000000000000000000000000000000000000000000

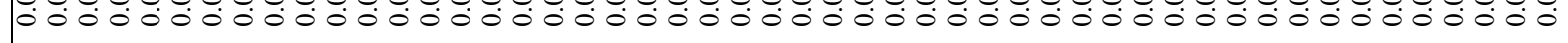

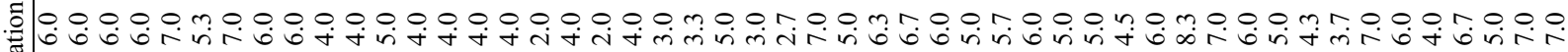

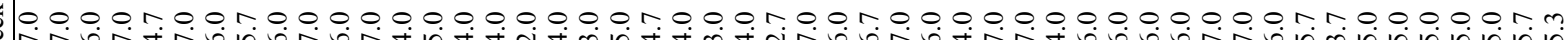

W 00000000000000000000000000000000000000000000000000

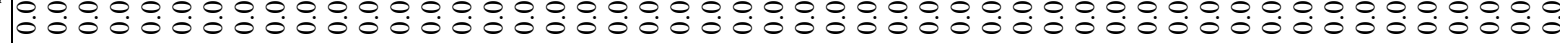

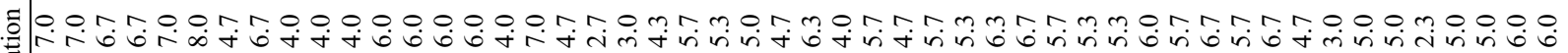

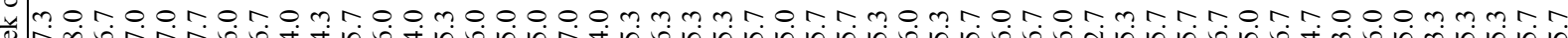

m

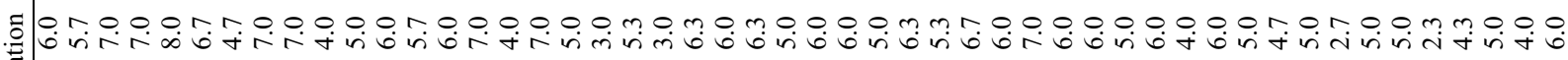

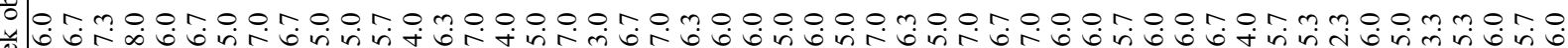
过

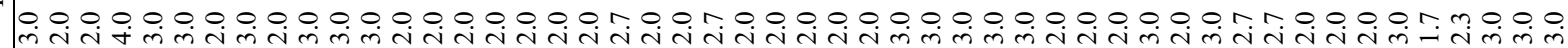

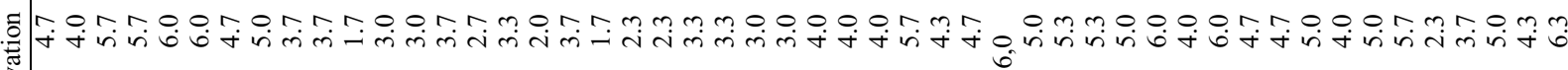

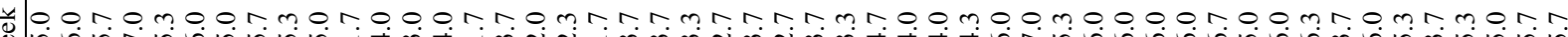
蒡

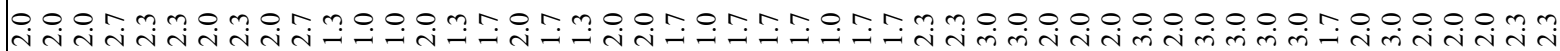

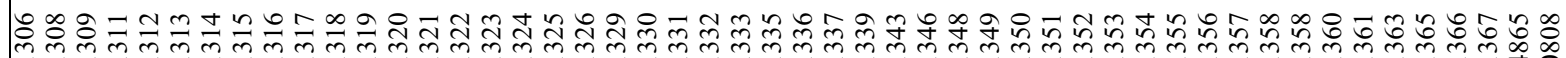

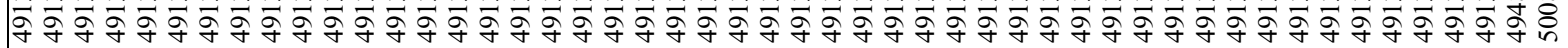

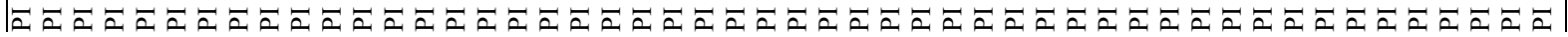




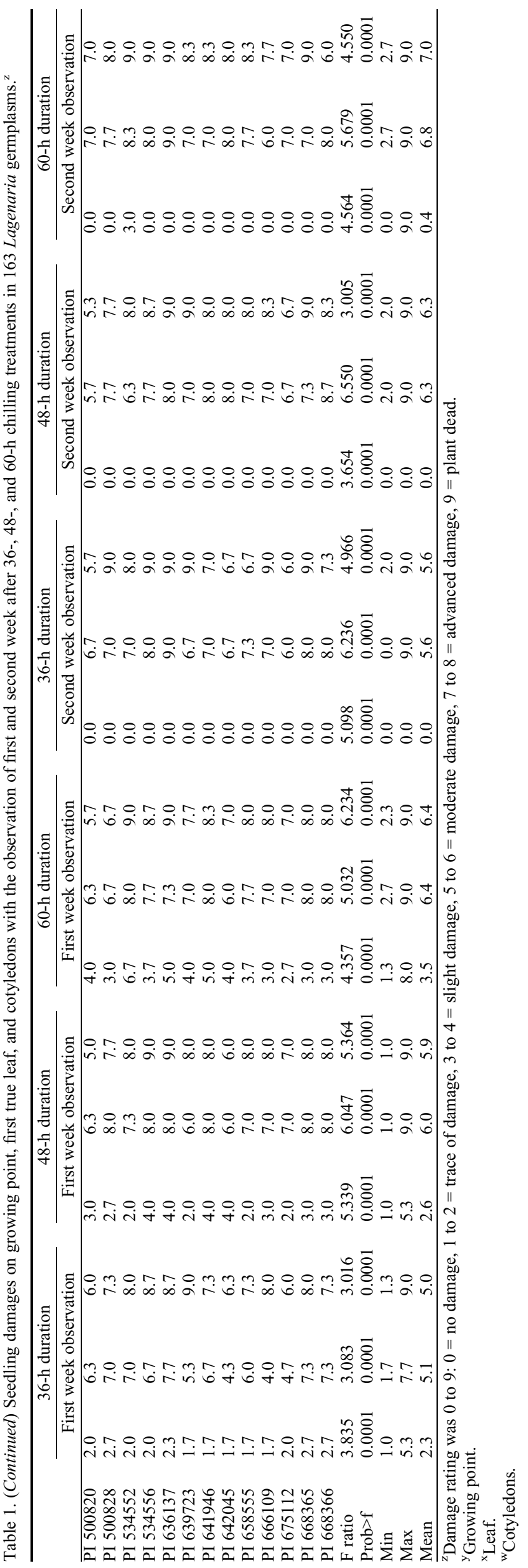

planted; however, only 163 accessions germinated sufficiently to be evaluated in this experiment. Seeds were sown in 48-cell flats filled with a mixture of sand and peat in a $1: 1$ ratio. After sowing, the flats were placed in a $37 \mathrm{~m}^{2}$ environmentally controlled greenhouse at the North Carolina State University Phytotron. The greenhouse was set to maintain the air temperature at $26 / 22 \pm 3.0{ }^{\circ} \mathrm{C}$ (day/night), $400 \mathrm{ppm} \mathrm{CO}_{2}, 50 \%$ relative humidity, and a 14-h photoperiod that was supplemented using sixteen $1000-\mathrm{W}$ metal halide lamps. Plants were watered twice daily, in the morning with a standard phytotron nutrient solution (Thomas et al., 2005) and afternoon with reverse osmosis water. The seeds of each accession were sown with five replications of two seeds each with randomized block experimental design. Seedlings were kept in the greenhouse until the first true leaf stage.

Chilling treatments. Chilling tests were performed according to the method of Kozik and Wehner (2014) with some modifications. The seedling flats were moved from the greenhouse to the chilling chambers when the seedlings reached the first true leaf stage. Chilling treatments were conducted in environmentally controlled plant growth chambers set to maintain a constant $4.0 \pm 0.5^{\circ} \mathrm{C}$ with a constant light intensity of $\approx 450 \mathrm{mmol} \cdot \mathrm{m}^{-2} \cdot \mathrm{s}^{-1}$. Seedlings were kept under chilling conditions for a duration of 36,48 , or $60 \mathrm{~h}$ before being returned to the greenhouse. Control plants were left unchilled (without moving to a chilling room, in the same greenhouse) as a reference for the rating scale (damage rating of 0 ). The manifestation of chilling damage as water-soaked patches afterward turning yellow or necrotic occurred some days after chilling treatments on the shoots (cotyledons, true leaves, and growing points). Plants were rated 7 and $14 \mathrm{~d}$ after chilling for damage on the cotyledons, first true leaf, and growing point for each plant in each plot. The scale used was 0 to $9: 0=$ no damage (based on the unchilled control plants), 1 to $2=$ trace of damage, 3 to $4=$ slight damage $(20 \%$ to $50 \%$ of tissue necrotic), 5 to $6=$ moderate damage $(50 \%$ to $70 \%$ of tissue necrotic), 7 to $8=$ advanced damage $(70 \%$ to $90 \%$ of tissue necrotic), $9=$ plant dead $(90 \%$ to $100 \%$ tissue necrotic) (Kozik and Wehner, 2014). Figure 1 shows the scale of 0 to 9 on the cotyledons and first true leaves in Lagenaria.

Experiment design and data analysis. The experiment was conducted in a randomized complete block design with three replications. The effects of the chilling treatments were subjected to analysis of variance by 36,48 , or $60 \mathrm{~h}$. Data were analyzed by the TABULATE and GLM procedures of SAS v9.0 Statistical Software Package (SAS Institute, Cary, NC). Mean separations of cultigens were tested using Fisher's protected least significant difference at $\alpha=0.05$. The most susceptible or tolerant cultigens were chosen based on damage rating. 


\section{Results and Discussion}

Damage rating after 1 and 2 weeks CI are shown on Table 1 and Fig. 2. At $36 \mathrm{~h}$ chilling duration, seedling damage on growing point ranged 1.0 to 5.3 (average 2.3 ), true leaf ranged 1.7 to 7.7 (average 5.1), and cotyle- dons ranged 1.3 to 9.0 (average 5.0). At $48 \mathrm{~h}$ chilling duration, seedling damage on growing point ranged 1.0 to 5.3 (average 2.6), true leaf ranged 1.0 to 9.0 (average 6.0), and cotyledons ranged 1.0 to 9.0 (average 5.9). At $60 \mathrm{~h}$ chilling duration, seedling damage on growing point ranged 1.3 to 8.0 (average 3.5 ),

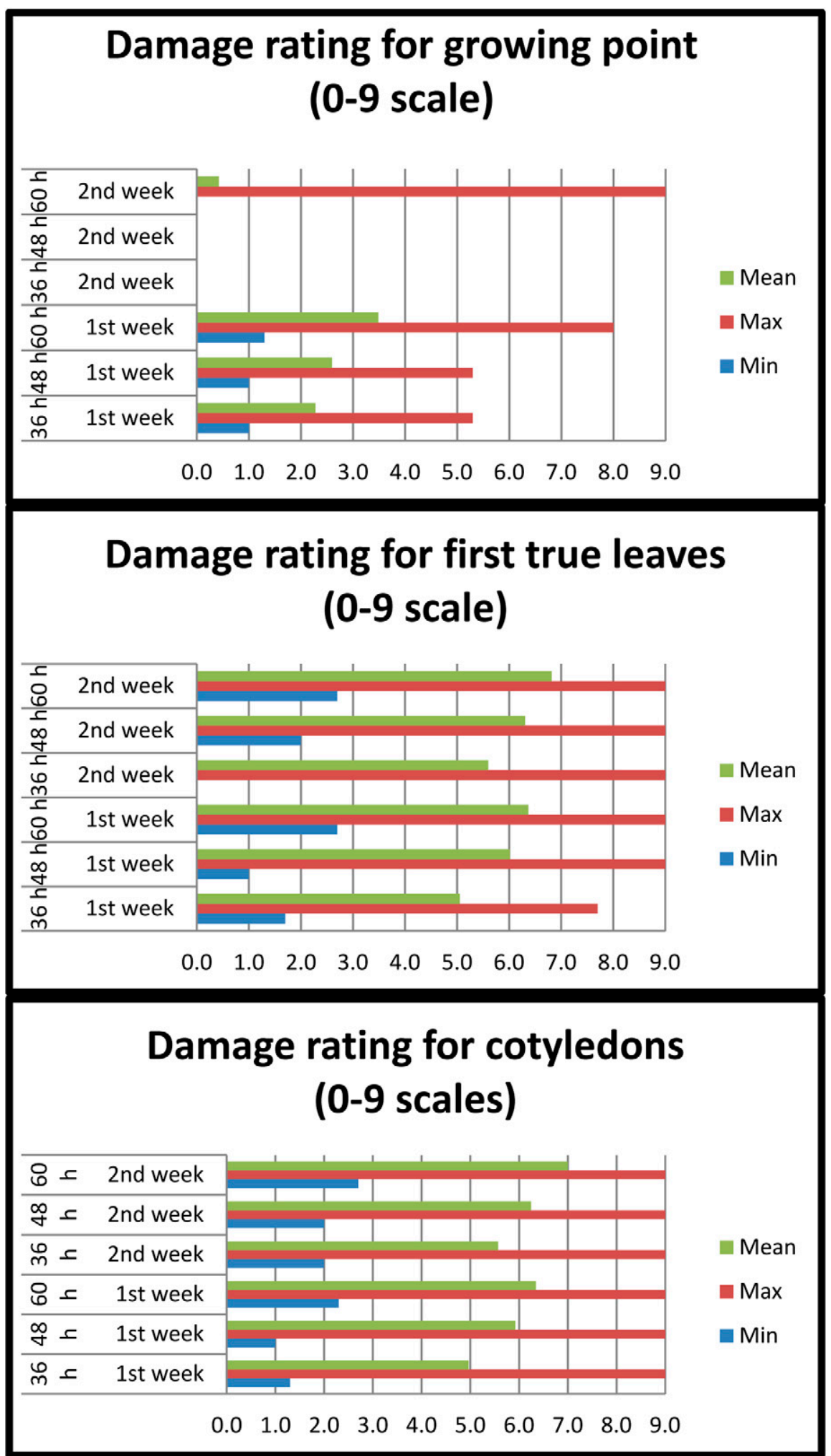

Fig. 2. Minimum, maximum, and mean of seedling damages on growing point, first true leaves, and cotyledons with the observation of first and second week after 36-, 48-, and 60-h chilling treatments. true leaf ranged 2.7 to 9.0 (average 6.4), and cotyledons ranged 2.3 to 9.0 (average 6.4). As chilling duration increased, seedling damage increased.

The accessions tested in this research were mostly tolerant to the cold injury. The most tolerant were PI 491272, PI 491280, PI 491281, PI 491286, and PI 491326 and the most susceptible were PI 381845, PI 381846 , PI 534556, PI 636137, and PI 668365 (Fig. 3A). Average chilling rating for the most tolerant and most susceptible PI accessions on first true leaf with the observation of first week after 36-h, 48-h, and 60-h treatments is shown in Table 2. As can be seen from the Table 2, although the scale value varies between 0 and 4 in tolerant accessions, these values were observed between 7 and 9 in susceptible accessions.

Two weeks after chilling treatment, Lagenaria seedlings no longer showed damage to the growing point, and had recovered in the greenhouse (Fig. 3B) from the 36-h and 48-h applications. Plants treated for $60 \mathrm{~h}$ had only a small amount of damage to the growing point in a few of the accessions. At $36 \mathrm{~h}$ chilling duration, seedling damage on true leaf ranged from 0.0 to 9.0 (average 5.6), and cotyledons ranged from 2.0 to 9.0 (average 5.6). At $48 \mathrm{~h}$ chilling duration, seedling damage on true leaf ranged from 2.0 to 9.0 (average 6.3), and cotyledons ranged from 2.0 to 9.0 (average 6.3). At $60 \mathrm{~h}$ chilling duration, seedling damage on true leaf ranged from 2.7 to 9.0 (average 6.8); and cotyledons ranged from 2.7 to 9.0 (average 7.0).

In our study, most of the bottle gourd accessions were highly tolerant, even at the longest chilling duration $(60 \mathrm{~h})$, at $4{ }^{\circ} \mathrm{C}$ and full light conditions. Spalholz and Kubota (2017) reported that watermelon (Citrullus lanatus) seedlings were generally chilling sensitive and therefore difficult to hold at low temperatures. However, the rootstocks used for watermelon grafting, interspecific squash (Cucurbita maxima $\times$ C. moschata) and bottle gourd (L. siceraria), are chilling tolerant. In our study, seedlings of bottle gourd (especially growing points) recovered from chilling damage, after they were transferred from the chilling chamber to the greenhouse for a few weeks, even if there was significant damage to the cotyledons and true leaves. These results are similar to the watermelon chilling results of Kozik and Wehner (2014), showing that chilling damage was lowest on the growing point and higher on the leaves and cotyledons.

In conclusion, the most tolerant bottle gourd accessions of the 163 tested were PI 491272, PI 491280, PI 491281, PI 491286, and PI 491326. In future studies, grafting success and compatibility tests should be evaluated for those accessions, as well as the effects of those rootstocks on yield and fruit quality of watermelon scions. However, gourd is also consumed as a vegetable in different parts of the world. It is also suggested that in some Asian and African countries where bottle gourd is consumed as a vegetable, these tolerant accessions can be 


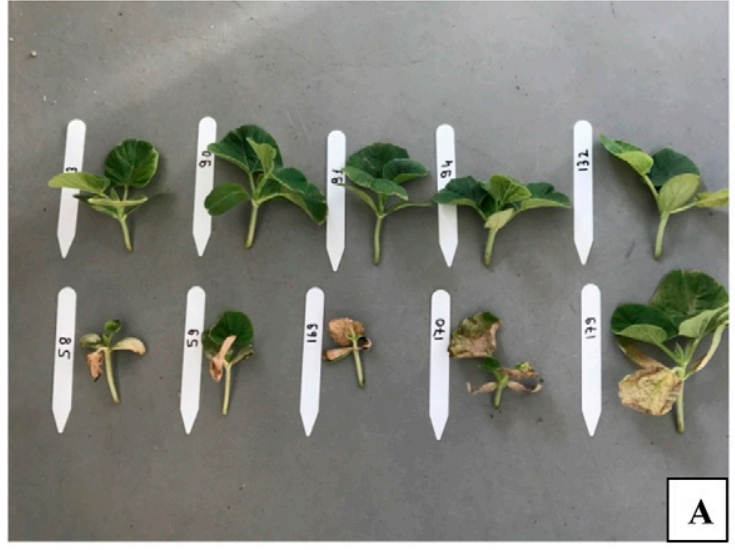

Fig. 3. Most tolerant (upper): $83=$ PI 491272, $90=$ PI 491280, $91=$ PI 491281, $94=$ PI 491286, $132=$ PI 491326, and most susceptible (lower) accessions: $58=$ PI 381845, $59=$ PI 381846, $169=$ PI 534556 , $170=$ PI $636137,179=$ PI 668365 after 1 week of chilling treatment $(\mathbf{A})$; recovering of plant growing points 2 weeks after chilling treatment $(\mathbf{B})$.

Table 2. Average chilling rating for the most tolerant and most susceptible PI accessions on first true leaf with the observation of first week after 36-, 48-, and 60-h treatments in 163 Lagenaria accessions.

\begin{tabular}{|c|c|c|c|c|c|c|c|}
\hline \multirow[b]{2}{*}{ Cultigen code } & \multirow[b]{2}{*}{ Accession } & \multicolumn{2}{|c|}{$36 \mathrm{~h}$} & \multicolumn{2}{|c|}{$48 \mathrm{~h}$} & \multicolumn{2}{|c|}{$60 \mathrm{~h}$} \\
\hline & & Mean & $\overline{\mathrm{SD}}$ & Mean & $\overline{\mathrm{SD}}$ & Mean & $\overline{\mathrm{SD}}$ \\
\hline & \multicolumn{7}{|c|}{ Most tolerant PI accessions } \\
\hline 83 & PI 491272 & 0.0 & 0.0 & 2.0 & 0.0 & 3.3 & 2.5 \\
\hline 90 & PI 491280 & 2.0 & 0.0 & 4.7 & 0.6 & 5.0 & 0.0 \\
\hline 91 & PI 491281 & 2.3 & 1.2 & 2.0 & 0.0 & 4.0 & 0.0 \\
\hline 94 & PI 491286 & 4.0 & 0.0 & 3.0 & 0.0 & 5.7 & 1.2 \\
\hline 132 & PI 491326 & 3.0 & 0.0 & 3.0 & 0.0 & 3.0 & 1.7 \\
\hline \multicolumn{8}{|c|}{ Most susceptible PI accessions } \\
\hline 58 & PI 381845 & 8.0 & 0.0 & 8.0 & 0.0 & 9.0 & 0.0 \\
\hline 59 & PI 381846 & 9.0 & 0.0 & 8.0 & 0.0 & 8.7 & 0.6 \\
\hline 169 & PI 534556 & 8.0 & 0.0 & 7.7 & 0.6 & 8.0 & 0.0 \\
\hline 170 & PI 636137 & 9.0 & 0.0 & 8.0 & 0.0 & 9.0 & 0.0 \\
\hline 179 & PI 668365 & 8.0 & 0.0 & 7.3 & 1.2 & 7.0 & 1.7 \\
\hline$F$ ratio & & 17.338 & - & 13.446 & - & 8.841 & - \\
\hline Prob $>F$ & & $<0.0001$ & - & $<0.0001$ & - & $<0.0001$ & - \\
\hline LSD $(0.05)$ & & 1.106 & - & 0.644 & - & 1.327 & - \\
\hline Minimum & & 0.0 & - & 1.0 & - & 1.0 & - \\
\hline Maximum & & 9.0 & - & 9.0 & - & 9.0 & - \\
\hline
\end{tabular}

LSD $=$ least significant difference.

used to develop cold-tolerant bottle gourd varieties.

\section{Literature Cited}

Bertucci, M.B., D.H. Suchoff, K.M. Jennings, D.W. Monks, C.C. Gunter, J.R. Schultheis, and F.J. Louws. 2018. Comparison of root system morphology of Cucurbit rootstocks for use in watermelon grafting. HortTechnology 28:629-636.

Chung, S.M., J.E. Staub, and G. Fazio. 2003 Inheritance of chilling injury: A maternally inherited trait in cucumber. J. Amer. Soc. Hort. Sci. 128:526-530.

Diao, Q.N., S.B. Tian, Y.Y. Chen, H.N. Xiong, and Y.P. Zhang. 2019. Response of endogenous nitric oxide and sucrose metabolizing to chilling stress in melon seedlings. Acta Botanica Boreali-Occident. Sinica 39(3):498-505.

Dong, Z., Y. Men, Z. Li, Q. Zou, and J. Ji. 2019. Chlorophyll fluorescence imaging as a tool for

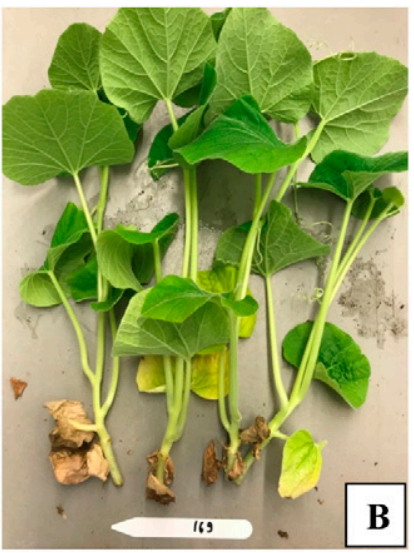

under low temperature. Acta Hort. 710:377382.

Kombo, M.D. and N. Sari. 2019. Rootstock effects on seed yield and quality in watermelon. Hort. Environ. Biotechnol. 60:303-312.

Kozik, E.U., U. Klosinska, and T.C. Wehner. 2007. New sources of chilling resistance in cucumber, p. 227-232. In: P. Nowaczyk (ed.). Spontaneous and induced variation for the genetic improvement of horticultural crops. University Press, University of Technology and Life Sciences, Bydgoszcz, Poland.

Kozik, E.U. and T.C. Wehner. 2008. A single dominant gene $\mathrm{Ch}$ for chilling resistance in cucumber seedlings. J. Amer. Soc. Hort. Sci. 133:225-227.

Kozik, E.U. and T.C. Wehner. 2014. Tolerance of watermelon seedlings to low-temperature chilling injury. HortScience 49:240-243.

Levi, A., J. Thies, K.S. Ling, A.M. Simmons, C. Kousik, and R. Hassell. 2009. Genetic diversity among Lagenaria siceraria accessions containing resistance to root-knot nematodes, whiteflies, ZYMV or powdery mildew. Plant Genet. Resour. 7(3):216-226.

Li, J. 2012. Effects of chilling and low light on vegetative and physiological parameters of melon seedlings. J. Henan Agricultural Sci. 41(5):106-109.

Liu, H.Y., Z.J. Zhu, G.H. Lu, and Q.Q. Qian. 2003. Chilling tolerance and physiological parameters as influenced by grafting in watermelon seedlings. Agr. Sci. China 2(10):1164-1169.

Liu, B., J. Ren, Y. Zhang, J. An, M. Chen, H. Chen, C. $\mathrm{Xu}$, and H. Ren. 2015. A new grafted rootstock against root-knot nematode for cucumber, melon, and watermelon. Agron. Sustain. Dev. 35:251-259.

Oda, M. 1995. New grafting methods for fruitbearing vegetables in Japan. Jpn. Agr. Res. Qrtly. 29:187-198.

Raison, J.K. 1974. A biochemical explanation of low temperature stress in tropical and subtropical plants. Bull. R. Soc. N. Z. 12:487-497.

Smeets, L. and T.C. Wehner. 1997. Environmental effects on genetic variation of chilling resistance in cucumber. Euphytica 97:217-225.

Spalholz, H. and C. Kubota. 2017. Rootstock affected in-and poststorage performance of grafted watermelon seedlings at low temperature. HortTechnology 27:93-98.

analyzing the effects of chilling injury of tomato seedlings. Scientia Hort. 246:490-497.

FAO. 2017. FAOSTAT Statistical Databases. 6 Jan. 2020. <http://www.fao.org/faostat/en/\#data/QC > .

Ghanbari, F., S. Fatahi, M. Mohammadi, and A.A Shayan. 2018. Improvement of tolerance to chilling in watermelon seedlings with methyl jasmonate and methyl salicylate. Thai J. Agr. Sci. 51(1):1-9.

King, S.R., A.R. Davis, X.P. Zhang, and K. Crosby. 2010. Genetics, breeding and selection of rootstocks for Solanaceae and Cucurbitaceae. Scientia Hort. 127:106-111.

Kong, Q.S., J.L. Chen, Y. Liu, Y.H. Ma, P. Liu, S.Y. Wu, and Z.L. Bie. 2014. Genetic diversity of Cucurbita rootstock germplasm as assessed using simple sequence repeat markers. Scientia Hort. 175:150-155

Ko, B.R., S.W. Kwon, M.J. Jaskani, and J.S. Choi. 2006. Fatty acid composition and fad3 gene expression in roots of watermelon and gourd
Thomas, J.F., R.J. Downs, and C.H. Saravitz. 2005. Phytotron procedural manual for controlled environment research at the southeastern plant environment laboratory. NCARS Tech. Bull. 244 (revised)

Xing, N.L., H.B. Zhang, Y.E. Wang, Y.P. Huang, and Y.H. Wang. 2017. Analysis of indexes for identification of tolerance of bottle gourd rootstock seedlings to low temperature and poor light. Acta Agr. Jiangxi 29(9):22-26.

Yetisir, H. and N. Sari. 2003. Effect of different rootstock on plant growth, yield and quality of watermelon. Austral. J. Exp. Agr. 43(10):1269 1274.

Zhang, Y.P., X.Q. Yao, S.J. Yang, S. Xu, and Y.Y. Chen. 2017. Effects of low temperature treatment and recovery on the photosynthesis and antioxidant characteristics in melon seedlings. Acta Agr. Shanghai 33(1):41-49. 